\title{
Higher Seed Production through IPNM in Cajanas Cajan Linn. (Mill. Sp.)
}

\author{
B. M. Rajurkar \\ Vice Principal, R. S. Bidkar Arts, Commerce and Science College, Hinganghat DistWardha, Maharashtra, India
}

Received November 15, 2020; Revised December 8, 2020; Accepted January 28, 2021

\section{Cite This Paper in the following Citation Styles}

(a): [1] B. M. Rajurkar, "Higher Seed Production through IPNM in Cajanas Cajan Linn. (Mill. Sp.)," Universal Journal of Agricultural Research, Vol. 9, No. 2, pp. 48-56, 2021. DOI: 10.13189/ujar.2021.090203.

(b): B. M. Rajurkar (2021). Higher Seed Production through IPNM in Cajanas Cajan Linn. (Mill. Sp.). Universal Journal of Agricultural Research, 9(2), 48-56. DOI: 10.13189/ujar.2021.090203.

Copyright $(2021$ by authors, all rights reserved. Authors agree that this article remains permanently open access under the terms of the Creative Commons Attribution License 4.0 International License

\begin{abstract}
The success of green revolution depends upon the availability of fertilizers, high yielding variety of seeds, improved agronomical practices and timely availability of water. In the present investigation, experimentation was conducted on plant Cajanas cajan of family papilionaceae. An attempt was made through different parameters like height of plants, number of branches per plants, number of pods per plants, dry seed weight per plants. In the experimentation, the effect of biofertilizer individually, in two (twins), and three (thrice) biofertilizers in combinations were observed. The effect of biofertilizer individually, in two, and three biofertilizers in combinations with NPK fertilizers were observed. The effect of biofertilizer individually, in two, and three biofertilizers in combinations with NPK fertilizers and macronutrients were observed. The effect of biofertilizer individually, in two, and three biofertilizers in combinations with NPK fertilizers, macronutrients and micronutrients were observed. Through these observations it had been observed that, in all parameters, biofertilizer individually, in two, and three biofertilizers in combinations with NPK fertilizers, macronutrients and micronutrients were beneficial for plants in achieving the higher production.
\end{abstract}

Keywords Biofertilizers, Integrated Plant Nutrient Management, Macronutrients, Micronutrients

\section{Introduction}

The term biofertilisers refers to microorganisms which either fix atmospheric nitrogen or enhance the solubility of soil nutrients in association with plant roots, symbiotic relationship and also in rhizosphere i.e. non symbiotic nitrogen fixation by legumes, Hellriegel and Wilfarth (1988).The first nitrogen fixing bacterium isolated from root nodules of legumes was Bacillus radicicola (Rhizobium sp.,), Beijerinck (1888), Azotobacter sp., and Azospirillum sp., Beijerinck (1925). The scientific developments, techniques in the study of soil microorganisms were innovated like direct soil examination, Conn, (1918) and Cholodny, (1930). Harley and Waid (1948) expressed the phosphate mobilization by ectomycorrhizal fungi. The work of nitrogen fixation in nodulated plants other than legumes was taken up by Quispel (1947), in Europe who made considerable headway on this work between 1950 and 1970.

Integrated Plant Nutrient Management (IPNM) aims to optimize the condition of the soil, with regards to its physical, chemical, biological and hydrological properties, for the purpose of enhancing farm productivity, and minimizing land degradation. There is now greater awareness that IPNM can, not only provide tangible benefits in terms of higher yields, but simultaneously and almost imperceptibly conserve the soil resource itself. The field level management practices considered under the heading of IPNM would include the use of farmyard manures, natural and mineral fertilizers, soil amendments, crop residues and farm wastes, agroforestry and tillage practices, green manures, cover crops, legumes, intercropping, crop rotations, fallows, irrigation, drainage, plus a variety of other agronomic, vegetative and structural measures designed to conserve both water and soil. 
It is only after they have made improvements in the biological, physical and hydrological properties of their soils that farmers can expect to get the full benefits from the supply of additional plant nutrients, in the form of inorganic fertilizer, to their crops. Production efficiencies are gained through the integrated nutrient management practices promoting combined use of mineral, organic and biological resources in a reasoned way to balance efficient use of limited/finite resources and ensure ecosystem sustainability against nutrient mining and degradation of soil and water resources. For example, efficient fertiliser use requires that correct quantities be applied (overuse of Nitrogen $(\mathrm{N})$ fertilizer risks disrupting the natural $\mathrm{N}$-cycle), and that the application method minimizes losses to air and/or water. Options exist for incorporating fertilizer into the soil directly (rather than broadcasting). Several phosphate solubilising microorganisms have been isolated and made their cultures, Chhonkar and Subba Rao, (1967).

The present investigation was undertaken with following objectives:

1. To experiment suitable plant Cajanas cajan Linn.

2. To evaluate different parameters like height of plants, number of branches per plants, number of pods per plants, dry seed weight per plants.

3. To investigate the effect of biofertilizer individually, in two (twins), and three (thrice) in combinations.

4. To investigate the effect of biofertilizer individually, in two (twins), and three (thrice) in combinations with NPK fertilizers.

5. To investigate the effect of biofertilizer individually, in two (twins), and three (thrice) in combinations with NPK fertilizers and macronutrients.

\section{Materials and Method}

To get the better results, some of the factors were studied, like study of soil, cropping systems, residual nutrients available in soil, $\mathrm{pH}$, moisture contents, preparation of fields for cropping etc. First the soil was collected, bagged, dried under laboratory conditions, crushed, processed, analysed for residual nutrients present in them to ensure the requirement of chemical fertilizers to experimental fields/plants. Dosages of chemical fertilizers were planned in two dosages. Cropping system was planned, as per recommendation/manuals of Punjabrao Agriculture University, Akola (M.S). Broth cultures of Rhizobia's of respective species in Norris and Date,(1976), and Its Modified Medium, Azotobacters sp. in Jensen's Medium (1976), and Jensen's Modified Medium.Azospirillum $s p$. and Pseudomonas $s p$ in Pikovskaia's Medium (1963), and its Modified medium.were prepared having higher growth period and kept ready for fertilization after plants were ready to fertilization.
Collection of Azotobacter chroococcum from soil: Azotobacter was procured from rhizosphere of plants, from 10-30 cm depth of soils from experimental fields of R. S. Bidkar College, Hinganghat Dist. Wardha.

Isolation of Azotobacter: Isolation of Azotobacter was made through the soil dilution plating method. A ten gram of soil sample was mixed with $100 \mathrm{ml}$ of sterile distilled water further, and serial dilutions of the suspensions were made using sterile distilled water. Suitable nitrogen free Jensen's agar medium, a specific for Azotobacter was made and poured into sterile petriplates. The cooled plates were kept for incubation at $30^{\circ} \mathrm{C}$ for 3-4 days. Mucoid colonies of soft milky Azotobacter were appeared on agar plate. The young cells do not show pigmentation but the older cells showed pigmentation. The pigment of Azotobacter chroococcum was black to brown. They were gram-negative, aerobic in nature belonging to Azotobacteriaceae of division Mendosicutes of kingdom Prokaryoteae.

Collection of phosphate solubilising organism (PSB) from soil: The PSB organisms were collected and isolated from the rhizosphere of plants from $20 \mathrm{~cm}$ depth of the soil of R. S. Bidkar College, Hinganghat Dist. Wardha.

Isolation of Phosphate Solubilising Bacteria (PSB): Ten grams of sample were suspended in $100 \mathrm{ml}$ distilled water. The serial dilutions of suspension were made and plated on phosphate containing media, (Pikovskaia's medium) for isolation. The plates were incubated upto two weeks at $28-30^{\circ} \mathrm{C}$. The transparent zone of about $1 \mathrm{~cm}$ around microbial colonies indicates the phosphate solubilization. These colonies were picked up and transferred in slants.

Collection of Rhizobia from Root Nodules: The Rhizobia were isolated from the root nodules of Cajanuscajan, (Maruti), from the fields of the R. S. Bidkar College, Hinganghat Dist. Wardha.

Isolation of Rhizobia from Nodules: The root nodules were collected from the Cajanus cajan, plants. Wealthy, fully matured and pink nodules were selected, washed and kept undamaged in 95 per cent ethanol for 5-10 seconds in sterilized petridishes and rinsed with sterile water. They were sterilized with 0.1 per cent mercuric chloride and washed with sterile water. The sterilized nodules were cultured on agar plates containing growth media. The growth medium, (Norris, and Date, 1976) medium was used for isolation and then the Rhizobia were transferred to broth cultures.

\section{Culture Techniques:}

Glassware's: The glassware were soaked and rinsed thoroughly with tap water followed by distilled water. The glassware were soaked for a minimum of 2-4 hours in 4 per cent analar grade $\mathrm{HCl}$ or $\mathrm{H}_{2} \mathrm{SO}_{4}$ and rinsed seven times with glass distilled water. They were dried in oven at $120^{\circ} \mathrm{C}$. The pipetteman tips of Gilson pipette used for 
preparation of media, sub culturing of algae and traces of other microorganisms were washed with teepol, tap water, 4 per cent analar grade $\mathrm{H}_{2} \mathrm{SO}_{4}$ or $\mathrm{HCl}$ and double distilled water. Then all the glassware was sterilized in the autoclave.

Culture flask/Vessels: The experiments, culturing, sub culturing of micro- organisms was carried out in conical flasks of 150-250 ml capacity. Pre sterilized glass petri plates were used for solid media. Test tubes of $25 \mathrm{ml}$ capacity were used to study the influence of element on growth.

Chemicals: All chemicals used in the experiment were Sigma or BDH analar grade.

Distilled water: Double distilled water was made through distillation unit of glass. The double distilled water was used for preparation of media, stock solutions, metal solutions, standard and other reagents and also mass cultures of biofertilisers/ microorganisms.

Selection of Media: A suitable media for Azotobacter chroococcum was Jensen's medium, Pseudomonas striata in Pikovskays,s medium, Rhizobium in Norris and Date's medium.

Autoclaving: Culture Media, standards and distilled water, pipetteman tips, needles, forceps, etc., were sterilized in autoclave at 15 pounds per square inch in excess of the atmospheric pressure which is equivalent to a temperature of $120^{\circ} \mathrm{C}\left(250^{\circ} \mathrm{F}\right)$ at sea level.

Inoculation: An inoculation of the organisms was carried out in the inoculation chamber. Before inoculation the chamber was fully saturated with absolute alcohol, the ultraviolet light was put on for an hour for destruction of other living cells, after one hour, the inoculation was made aseptically with the help of sterilized loop. The cultures were maintained at a photon plus density 20-30 $\mu$ and photon $\mathrm{M}^{-2} \mathrm{~S}^{-1}$.

Estimation of Growth: The growth of these bacteria was observed in measuring optical density at $660 \mathrm{~nm}$ for bacteria and $675 \mathrm{~nm}$ for cyanobacteria by using UV-spectrophotometer.

Analysis of Soil samples: The soil samples were collected from the fields of R. S. Bidkar College, Hinganghat Dist. Wardha. Each soil sample was taken from a depth of roots about $20-30 \mathrm{~cm}$ in a zig-zag manner. A representative composite soil sample was also taken into account.The most significant discovery was that the German chemist Justus Von Liebig (1840) showed that the growing plants obtain elements calcium, potassium, sulphur and phosphorous from the soil.

Preparation of soil samples: The soil samples were dried at room temperature and then passed through $2 \mathrm{~mm}$ sized sieve and stored in a clean polyethylene bags and labeled with necessary information of field, collection date and time etc. The main purpose for which samples were collected for: Soil fertility evaluation and fertilizer recommendation.

Determination of Soil pH: The $\mathrm{pH}$ of soil was measured with the $\mathrm{pH}$ meter. An aliquot was made by selecting $20 \mathrm{gm}$ of soil in $40 \mathrm{ml}$ of distilled water (1:2 ratio) in a $50 \mathrm{ml}$ beaker and a aliquot was kept on a shaker for half an hour, then filter through the filter paper in another beaker, and $\mathrm{pH}$ was measured with the help of standarised pH meter. Similarly, Electrical Conductivity (Total salts) of soil, Moisture content (Oven dry method).

Application of Biofertilisers, NPK and other macro and micronutrients on crops: Plants require nutrients for growth and development. The German Botanist Julius Von Sachs (1860) discovered ten nutrient elements to be essential and they were used in synthetic mineral solutions for the growth of plants. These nutrients were absorbed by plants from the soil. In the soil, there are large numbers of nutrients or elements present in various forms. The elements are classified into macronutrients or major nutrients and Micronutrients or minor nutrients.

Macronutrients: Plants use macronutrients in relatively large quantities, Carbon, Hydrogen, Oxygen, Nitrogen, Phosphorus, Potassium, Calcium, Magnesium and Sulphur, Out of these elements, Nitrogen, Phosphorus and Potassium are considered be primary nutrients and magnesium, calcium and Sulphur as secondary plant nutrients. These nutrients primary and secondary collectively were called the major plant nutrients.

Micronutrients: The elements of micronutrients are used in field in a very-very small quantity or in a trace amount. They are Manganese, Iron, Molybdenum, Copper, Boron, Zinc and Chlorine but they are important as the major element in plant nutrition.

The field experiment was conducted on the farm of R. S. Bidkar College, Hinganghat Dist. Wardha during the session 2019-2020. Cajanas cajan crop variety was chosen to study, the Kharif crop.Cajanus cajan (Maroti var. IPCL-87119). The treatments given to these plants were control, that is without any inoculation of any biochemical fertilisers, where as other treatments given to seedling plants with inoculation of individuals and combination of Rhizobium and Azotobacter, Rhizobium and Pseudornonas, Rhizobium, Azotobacter and Pseudomonas; Pseudomonas and Azotobacter treatments with combination of all these with varied concentration of macro and micronutrients. The macro and micronutrient concentration to each crop selected as per ICAR recommendation and last treatment preferred only for chemical fertilisers.

All biofertilisers under these treatments were wild or laboratory strains. Near about 10-12 treatments were made to carry out the experimental study to find out an influence of each biofertilisers on Kharif. First, soil of the experimental fields were analysed for physico-chemical parameters. The soil was medium black, clay, rich in available nitrogen, potash and medium in available phosphorus and alkaline in $\mathrm{pH}$. The available macro and micronutrients showed variation in their concentration in the soil of chosen plots. The effect of individual treatment 
of each strain as well as in combination with biofertiliser and chemical fertilisers was studied on Kharif crops as recommended doses of chemical fertilisers and presence or absence of chemical nutrients in soils were taken into account in the experimental study. The biofertilisers were used in liquid forms and inoculated at the seedling stage of plants. The amount of inoculum was $1 \mathrm{ml} /$ plant. The chemical nutrients were supplied to each crop in the second week of sowing or at the timings of seedlings in different ratios (as per the requirements) with different plants with and without combinations of biofertilisers.

The details of treatments are given in Table (1) Cajanus cajan (Maroti):

Table 1. Chemical treatments

\begin{tabular}{|c|c|c|c|c|c|}
\hline N-level & Symbol & P-level & Symbol & K-level & Symbol \\
\hline $\begin{array}{c}0 \mathrm{~kg} \mathrm{~N} / \\
\text { ha }\end{array}$ & $\mathrm{N}_{0}$ & $\begin{array}{c}0 \mathrm{~kg} \mathrm{P} / \\
\text { ha }\end{array}$ & $\mathrm{P}_{0}$ & $\begin{array}{c}0 \mathrm{~kg} \mathrm{~K} / \\
\text { ha }\end{array}$ & $\mathrm{K}_{0}$ \\
\hline $\begin{array}{c}5 \mathrm{~kg} \mathrm{~N} / \\
\text { ha }\end{array}$ & $\mathrm{N}_{5}$ & $\begin{array}{c}10 \mathrm{~kg} \mathrm{P} / \\
\text { ha }\end{array}$ & $\mathrm{P}_{10}$ & $\begin{array}{c}10 \mathrm{~kg} \mathrm{~K} / \\
\text { ha }\end{array}$ & $\mathrm{K}_{10}$ \\
\hline $\begin{array}{c}10 \mathrm{~kg} \mathrm{~N} / \\
\text { ha }\end{array}$ & $\mathrm{N}_{10}$ & $\begin{array}{c}20 \mathrm{~kg} \mathrm{P} \\
\text { ha }\end{array}$ & $\mathrm{P}_{20}$ & $\begin{array}{c}20 \mathrm{~kg} \mathrm{~K} / \\
\text { ha }\end{array}$ & $\mathrm{K}_{20}$ \\
\hline $\begin{array}{c}15 \mathrm{~kg} \mathrm{~N} / \\
\mathrm{ha}\end{array}$ & $\mathrm{N}_{15}$ & $\begin{array}{c}30 \mathrm{~kg} \mathrm{P} / \\
\text { ha }\end{array}$ & $\mathrm{P}_{30}$ & $\begin{array}{c}30 \mathrm{~kg} \mathrm{~K} / \\
\text { ha }\end{array}$ & $\mathrm{K}_{30}$ \\
\hline $\begin{array}{c}20 \mathrm{~kg} \mathrm{~N} / \\
\mathrm{ha}\end{array}$ & $\mathrm{N}_{20}$ & $\begin{array}{c}40 \mathrm{~kg} \mathrm{P} / \\
\mathrm{ha}\end{array}$ & $\mathrm{P}_{40}$ & $\begin{array}{c}40 \mathrm{~kg} \mathrm{~K} / \\
\text { ha }\end{array}$ & $\mathrm{K}_{40}$ \\
\hline $\begin{array}{c}25 \mathrm{~kg} \mathrm{~N} / \\
\text { ha }\end{array}$ & $\mathrm{N}_{25}$ & $\begin{array}{c}50 \mathrm{~kg} \mathrm{P} / \\
\mathrm{ha}\end{array}$ & $\mathrm{P}_{50}$ & $\begin{array}{c}50 \mathrm{~kg} \mathrm{~K} / \\
\mathrm{ha}\end{array}$ & $\mathrm{K}_{50}$ \\
\hline
\end{tabular}

Table 2. I Biofertiliser treatments (Cajanuscajan)

\begin{tabular}{|c|c|}
\hline No treatment (control-uninoculated) & $\mathrm{T}_{0}$ \\
\hline Treatment with Rhizobium $\mathrm{sp}$ & $\mathrm{T}_{1}$ \\
\hline Treatment with Pseudomonas striata. & $\mathrm{T}_{2}$ \\
\hline Treatment with Azotobater chroococcum. & $\mathrm{T}_{3}$ \\
\hline Treatment with Rhizobium sp., + Pseudomonas striata. & $\mathrm{T}_{4}$ \\
\hline $\begin{array}{c}\text { Treatment with } \text { Rhizobium Sp., }+ \text { Azotobacter } \\
\text { chroococcum. }\end{array}$ & $\mathrm{T}_{5}$ \\
\hline $\begin{array}{c}\text { Treatment with } \text { Rhizobium sp., }+ \text { Pseudormonas } \\
\text { striata+Azotobacter chroococcum. }\end{array}$ & $\mathrm{T}_{6}$ \\
\hline
\end{tabular}

Table 3. II Chemical fertilisers + Biofertiliser treatments (I+ II)

\begin{tabular}{|c|c|}
\hline $\mathrm{T}_{6}+\mathrm{N}_{5}+\mathrm{P}_{10}+\mathrm{K}_{10}$ & $\mathrm{~T}_{7}$ \\
\hline $\mathrm{T}_{6}+\mathrm{N}_{10}+\mathrm{P}_{20}+\mathrm{K}_{20}$ & $\mathrm{~T}_{8}$ \\
\hline $\mathrm{T}_{6}+\mathrm{N}_{15}+\mathrm{P}_{30}$ & $\mathrm{~T}_{9}$ \\
\hline $\mathrm{T}_{6}+\mathrm{N}_{20}+\mathrm{P}_{40}+\mathrm{K}_{40}$ & $\mathrm{~T}_{10}$ \\
\hline $\mathrm{T}_{6}+\mathrm{N}_{25}+\mathrm{P}_{50}+\mathrm{K}_{50}$ & $\mathrm{~T}_{11}$ \\
\hline $\mathrm{T}_{6}+\mathrm{N}_{30}+\mathrm{P}_{90}+\mathrm{K}_{30}$ & $\mathrm{~T}_{12}$ \\
\hline Treatment only with $\mathrm{N}_{15}+\mathrm{P}_{30}+\mathrm{K}_{30}$ (Cajanus cajan) & $\mathrm{T}_{13}$ \\
\hline
\end{tabular}

Table 4. III Treatment with major and minor Chemical fertilisers + Bio-fertilisers (I + II + III) (Cajanuscajan)

\begin{tabular}{|c|c|c|c|}
\hline $\begin{array}{c}\mathrm{T}_{9}\left(\mathrm{~N}_{15}+\mathrm{P}_{30}+\mathrm{k}_{30)}+\right. \\
15 \mathrm{Kg} \mathrm{S} / \mathrm{ha}\end{array}$ & $\mathrm{T}_{14}$ & $\mathrm{~T}_{24}+2.0 \mathrm{Kg} \mathrm{Fe} / \mathrm{ha}$ & $\mathrm{T}_{28}$ \\
\hline $\mathrm{T}_{9}+30 \mathrm{Kg} \mathrm{S} / \mathrm{ha}$ & $\mathrm{T}_{15}$ & $\mathrm{~T}_{27}+0.5 \mathrm{Kg} \mathrm{Mn} / \mathrm{ha}$ & $\mathrm{T}_{29}$ \\
\hline $\mathrm{T}_{9}+45 \mathrm{Kg} \mathrm{S} / \mathrm{ha}$ & $\mathrm{T}_{16}$ & $\mathrm{~T}_{27}+1.0 \mathrm{KgMn} / \mathrm{ha}$ & $\mathrm{T}_{30}$ \\
\hline $\begin{array}{c}\mathrm{T}_{15}\left(\mathrm{~N}_{15}+\mathrm{P}_{30}+\mathrm{k}_{30}\right. \\
30 \mathrm{Kg} \mathrm{S} / \mathrm{ha})+30 \mathrm{Kg} \\
\text { Ca/ha }\end{array}$ & $\mathrm{T}_{17}$ & $\mathrm{~T}_{27}+1.5 \mathrm{Kg} \mathrm{Mn} / \mathrm{ha}$ & $\mathrm{T}_{31}$ \\
\hline $\mathrm{T}_{15}+40 \mathrm{Kg} \mathrm{Ca} / \mathrm{ha}$ & $\mathrm{T}_{18}$ & $\mathrm{~T}_{29}+0.5 \mathrm{Kg} \mathrm{Cu} / \mathrm{ha}$ & $\mathrm{T}_{32}$ \\
\hline $\mathrm{T}_{15}+50 \mathrm{Kg} \mathrm{Ca} / \mathrm{ha}$ & $\mathrm{T}_{19}$ & $\mathrm{~T}_{29}+1.0 \mathrm{Kg} \mathrm{Cu} / \mathrm{ha}$ & $\mathrm{T}_{33}$ \\
\hline $\mathrm{T}_{18}+15 \mathrm{Kg} \mathrm{Mg} / \mathrm{ha}$ & $\mathrm{T}_{20}$ & $\mathrm{~T}_{29}+1.5 \mathrm{Kg} \mathrm{Cu} / \mathrm{ha}$ & $\mathrm{T}_{34}$ \\
\hline $\mathrm{T}_{18}+30 \mathrm{Kg} \mathrm{Mg} / \mathrm{ha}$ & $\mathrm{T}_{21}$ & $\mathrm{~T}_{33}+0.5 \mathrm{KgB} / \mathrm{ha}$ & $\mathrm{T}_{35}$ \\
\hline $\mathrm{T}_{18}+45 \mathrm{Kg} \mathrm{Mg} / \mathrm{ha}$ & $\mathrm{T}_{22}$ & $\mathrm{~T}_{33}+1.0 \mathrm{Kg} \mathrm{B} / \mathrm{ha}$ & $\mathrm{T}_{36}$ \\
\hline $\mathrm{T}_{21}+10 \mathrm{Kg} \mathrm{Zn} / \mathrm{ha}$ & $\mathrm{T}_{23}$ & $\mathrm{~T}_{33}+1.5 \mathrm{KgB} / \mathrm{ha}$ & $\mathrm{T}_{37}$ \\
\hline $\mathrm{T}_{21}+15 \mathrm{Kg} \mathrm{Zn} / \mathrm{ha}$ & $\mathrm{T}_{24}$ & $\mathrm{~T}_{35}+0.5 \mathrm{Kg} \mathrm{Mo} / \mathrm{ha}$ & $\mathrm{T}_{38}$ \\
\hline $\mathrm{T}_{21}+20 \mathrm{Kg} \mathrm{Zn} / \mathrm{ha}$ & $\mathrm{T}_{25}$ & $\mathrm{~T}_{35}+1.0 \mathrm{Kg} \mathrm{Mo} / \mathrm{ha}$ & $\mathrm{T}_{39}$ \\
\hline $\mathrm{T}_{24}+1.0 \mathrm{Kg} \mathrm{Fe} / \mathrm{ha}$ & $\mathrm{T}_{26}$ & $\mathrm{~T}_{35}+1.5 \mathrm{Kg} \mathrm{Mo} / \mathrm{ha}$. & $\mathrm{T}_{40}$ \\
\hline $\mathrm{T}_{24}+1.5 \mathrm{Kg} \mathrm{Fe} / \mathrm{ha}$ & $\mathrm{T}_{27}$ & & \\
\hline
\end{tabular}

Table 5. Chemical fertilisers for fertilization (Chemical fertilisers used): The Nitrogen and Phosphorus contents in fertilisers were taken into account as follows

\begin{tabular}{|c|c|c|}
\hline \multirow{2}{*}{ Fertiliser } & \multicolumn{2}{|c|}{ Constituents in \% } \\
\cline { 2 - 3 } & $\mathrm{N}$ & $\mathrm{P}$ \\
\hline Urea & 46 & - \\
\hline Single superphosphate & - & 16 \\
\hline
\end{tabular}

Table 6. Chemicals Used to dressing the soils

\begin{tabular}{|c|c|c|}
\hline Name of chemical & Chemical Formula & Element \\
\hline $\begin{array}{c}\text { Potassium sulphate/ Muriate } \\
\text { potash }\end{array}$ & $\mathrm{K} \mathrm{SO}_{4}$ & $\mathrm{~K}$ \\
\hline Single superposhphate & $\mathrm{CaSO}_{4}$ & $\mathrm{Ca}$ \\
\hline Magnesium sulphate & $\mathrm{MgSO}_{4} 7 \mathrm{H} \mathrm{O}_{2}$ & $\mathrm{Mg}$ \\
\hline Calcium sulphate & $\mathrm{CaSO}_{4}$ & $\mathrm{~S}$ \\
\hline Zinc sulphate / Zinc oxide & $\mathrm{ZnSO}_{4} / \mathrm{ZnO}$ & $\mathrm{Zn}$ \\
\hline Manganese sulphate & $\mathrm{MnSO}_{4}$ & $\mathrm{Mn}$ \\
\hline Iron/ Ferrous sulphate & $\mathrm{FeSO}_{4}$ & $\mathrm{Fe}$ \\
\hline Boric acid & $\mathrm{H} \mathrm{PO}_{3}$ & $\mathrm{~B}$ \\
\hline Ammmonium molybdate & $(\mathrm{NH} 4) \mathrm{MoO}_{4}$ & $\mathrm{MO}$ \\
\hline Copper sulphate & $\mathrm{CuSO} .5 \mathrm{H} \mathrm{O}$ & $\mathrm{Cu}$ \\
\hline
\end{tabular}

The application of each fertilisers was taken into account on gross plot basis as per treatments. The soil was top dressed with chemical fertilisers before cropping or seedling plants were inoculated later with biofertiliser. 
Biofertilisers applied (used): The biofertiliser strains applied in the field study are Rhizobium wild strain of respective plants, Azotobarcter chroococcum and Pseudomonas striata.

Preparation of mass cultures: Stock cultures of different strains of biofertilisers were prepared in respective media for field experiments and their optical density was measured at $660 \mathrm{~nm} .1-\mathrm{ml}$ of mass culture was used for treatments per individual plants near the roots when soil was dry and lightly irrigated after inoculation.

Layouts for field experimentation: Two seasons, winter and summer seasons of 2019-2020, were selected and field was prepared by ploughing to a depth of $30 \mathrm{~cm}$ followed by harrowing with blade harrow to break the blocks into fine soil tilth and field was kept ready for sowing. The field was designed into plots as per layout plan.

Sowing details/ Sowing plan: All seeds of crop were sown at an optimum soil moisture condition in paired rows of a standard distance between rows and within two plants as per recommendations of PKV, Akola.

Distance between lines and plants: The Distance between two lines was kept $30 \mathrm{cms}$ and between two plants was kept $30 \mathrm{cms}$ for Cajanus cajan (Maroti var. IPCL-87119)

After vigorous experimentation and observations data was tabulated and depicted and analysed in tabulated forms.

Table 7. Representation of $\mathrm{pH}$, moisture content, electrical conductivity, available Macro and micro elements of soil

\begin{tabular}{|c|c|c|}
\hline Soil samples of crops & & Cajanuscajan \\
\hline $\mathrm{pH}$ & & 7.1 \\
\hline Moisture content & & 0.1 \\
\hline Electrical conductivity dSm-1 & & 0.02 \\
\hline \multirow{6}{*}{ Available Macronutrients $\mathrm{Kg} / \mathrm{ha}$} & $\mathrm{N}$ & 266.5 \\
\hline & $\mathrm{P}$ & 25.12 \\
\hline & $\mathrm{K}$ & 228.9 \\
\hline & $\mathrm{Ca}$ & 29 \\
\hline & $\mathrm{Mg}$ & 21 \\
\hline & $\mathrm{S}$ & 20 \\
\hline \multirow{6}{*}{ Available Micronutrients $\mathrm{kg} / \mathrm{ha}$} & $\mathrm{Zn}$ & 16 \\
\hline & $\mathrm{Fe}$ & 24 \\
\hline & $\mathrm{Mn}$ & 19 \\
\hline & $\mathrm{Cu}$ & 18 \\
\hline & $\mathrm{B}$ & 12 \\
\hline & Mo & 10 \\
\hline
\end{tabular}

\section{Observations and Results}

\section{Effect of Biofertilisers and Balanced nutrition}

Effect of biofertilisers alone on plant cannot give fruitful results but chemical fertilizers in combination of biofertiliser give more response and conductive effect on growth of crop plant. However, the composite inoculations with balanced nutrition supply to the plants shows more significant responses in biomass production at all stages of crop plants, like plant height, total number of branches, pods per plant and productivity of plant per hectare and test weight too.

The total productivity of crop plants has been compared between the crops.

1. Control: Crop without use of biofertiliser and chemical fertilisers.

2. Crops with use of biofertiliser alone.

3. Crops with use of major chemical fertilisers NPK.

4. Crops with use of both biofertiliser and major chemical fertilizer NPK.

5. Crops with use of biofertiliser, chemical fertilizers NPK, macro and micronutrients.

Effect of Pseudomonas striata and Azotobacter chroococcum with major chemical fertilizers NPK on plants height per plant (cms) of Cajanus cajan Linn

The individual inoculation of biofertilisers is always beneficial over the control - (no treatment) (Table 8). In the experimentation of Cajanus cajan Linn, the strains of biofertilisers like Pseudomonas striata and Azotobacter chroococcum were employed. The plant with Pseudomonas striata and Azotobacter chroococcum treatment showed maximum height per plant over the individual treatment with Azotobacter chroococcum and Pseudomonas striata strains. The results of Pseudomonas striata treatment, Azotobacter chroococcum and combination of both (two) were 100.0 and $200.0 \mathrm{cms}$, 105.5 and $108.5 \mathrm{cms}, 107.5$ and $107.0 \mathrm{cms}$ and of control 81.0 and $80.0 \mathrm{cms}$ plant height per plant. The observations in combination with Pseudomonas striata and Azotobacter chrroococcum treated plant in an average were most significant than other two of individual treatment and control.

It is also observed that when the combination of two strains of Pseudomonas striata and Azotobacter chroococcum tested with different doses of NPK, it showed more response in combination of two strains with chemical treatment. In an experiment, combination of two strains was common for different levels of $10 \mathrm{NaOaOK}$ $\mathrm{kg} / \mathrm{ha}, \quad 20 \mathrm{~N}: 20: 20 \mathrm{~K} \quad \mathrm{~kg} / \mathrm{ha}, \quad 30 \mathrm{~N}: 30: 30 \mathrm{~K} \quad \mathrm{~kg} / \mathrm{ha}$, $40 \mathrm{~N}: 40: 40 \mathrm{~K} \mathrm{~kg} / \mathrm{ha}$ and $50 \mathrm{~N}: 50: 50 \mathrm{~K} \mathrm{~kg} / \mathrm{ha}$. The results were 126.0 and $127.0 \mathrm{cms}$ per plant, 136.0 and 132.0 $\mathrm{cms} /$ plant. 138.0 and $134.0 \mathrm{cms}$ per plant, 148.0 and 148.0 cms per plant, 120.0 and $130.0 \mathrm{cms}$ per plant and of only chemical treatment at $50 \mathrm{~N}, 50 \mathrm{P}, 50 \mathrm{~K} \mathrm{~kg} / \mathrm{ha} 146.0$ and $145.0 \mathrm{cms}$ in an average per plant.

From observations, it is viewed that at $40 \mathrm{~N}, 40 \mathrm{P}, 40 \mathrm{~K}$ $\mathrm{kg} / \mathrm{ha}$ with combined inoculum of Pseudomonas striata and Azotobacter chroococcum was found to be significant for plant height per plant in an average. 
Effect of Pseudomonas striataand Azotobacter chroococcum with major chemical fertilizers NPK on No. of fruits / plant of Cajanus cajan Lin

The effect on number of fruits per plant was also observed in treatments with biofertilisers individually, in combination of biofertilisers of two strains of Pseudomonas striata and Azotobacter chroococcum. The result showed that the Number of fruit in combined inoculum was 19.0 and 19.0 in an average, in Azotobacter chroococcum treatment 17.0 and 15.0 in average, in Pseudomonas striata 14.0 and 13.0 in number in an average and in control; it was 11.0 and 11.0 in number. From table 9, it is evident that the combined inoculation was effective over the individual and control.

From table 9, it is viewed that the supplementation of NPK chemical fertilisers in different doses / levels with biofertilisers affects the number of fruits per plants. In experimentation, the combination of inoculum of two strains namely the Pseudmonas striata and Azotobacter chroococcum as a fixed strains but with different levels of NPK fertilisers viz. $10 \mathrm{~N}, 10 \mathrm{P}, 10 \mathrm{~K} \mathrm{~kg} / \mathrm{ha}, 20 \mathrm{~N}, 20 \mathrm{P}, 20 \mathrm{~K}$ $\mathrm{kg} / \mathrm{ha}, 30 \mathrm{~N}, 30 \mathrm{P}, 30 \mathrm{~K} \mathrm{~kg} / \mathrm{ha}, 40 \mathrm{~N}, 40 \mathrm{P}, 40 \mathrm{~K} \mathrm{~kg} / \mathrm{ha}, 50 \mathrm{~N}$, $50 \mathrm{P}, 50 \mathrm{~K} \mathrm{~kg} / \mathrm{ha}$ and only 50:50:50 NPK fertilisers (without biofertilisers) were tested and obtained the results, and they were 18.0 and 19.0, 32.0 and 36.0, 37.0 and 36.0, 33.0 and 34.0, 32.0 and 28.0 and 30.0 and 36.0 number of fruits per plants respectively. It is evident that the combination of twin inoculum of Pseudomonas striata and Azotobacter chroococcum with the $30: 30: 30 \mathrm{~kg} / \mathrm{ha}$ NPK fertilizers was found significant over the other treatments and significant over control also (Table 9).

Effect of Pseudomonas striataand Azotobacter chroococcum with major chemical fertilizers NPK on the yields of fruits (gms) per plant of Cajanus cajan Lin

In view of increase in height of plant per plant and number of fruit per plant, the yields of fruits (gms) per plants were experimented and tested. The application of only biofertilisers as a individual strains or in a combination of two strains can also influence the yield of fruits per plant (gms) (Table 10). It was observed that, the fruit yield in Pseudmonas striata treatment was 33.21 and $33.34 \mathrm{gms} / \mathrm{pt}$, Azotobacter chroococcum had 34.62 and $34.41 \mathrm{gms}$ per plant, and combination of these two had 36.129 and $37.020 \mathrm{gm} / \mathrm{pt}$. and the in control was 30.52 and 32.05 gms per plant in an average. It is evident that (table 10), the positive influence was observed in combination of two strains of biofertilisers namely the Pseudomonas striata sp and Azotobacter chroococcum over the individual inoculum of Pseudomonas striata and Azotobacter chroococcum also over the control too.

Further, it has been observed that the combination of two strain as a constant treatment with different doses of chemical fertilisers of NPK, 10N:10P:10K kg/ha, $20 \mathrm{~N}: 20 \mathrm{P}: 20 \mathrm{~K} \mathrm{~kg} / \mathrm{ha}, 30 \mathrm{~N}: 30 \mathrm{P}: 30 \mathrm{~K} \mathrm{~kg} / \mathrm{ha},-10 \mathrm{~N}: 40 \mathrm{P}: 40 \mathrm{~K}$ $\mathrm{kg} / \mathrm{ha}, 50 \mathrm{~N}: 50 \mathrm{P}: 50 \mathrm{~K} \mathrm{~kg} / \mathrm{ha}$ and $50 \mathrm{~N}: 50 \mathrm{P}: 50 \mathrm{~K} \mathrm{~kg} / \mathrm{ha}$ alone (without biofertilisers) showed the 50.235 and 50.352 gms/ plant, 72.283 and 72.389 gms per plant, 73.707 and $73.737 \mathrm{gms} /$ plant, 72.302 and 72.612 gms per plant, 72.273 and $72.263 \mathrm{gms} /$ plant and 49.638 and $48.912 \mathrm{gms}$ yields (gms) per plant in average. It was evident that the combination of two strains of biofertilisers with $30 \mathrm{~N}: 30 \mathrm{P}: 30 \mathrm{~K} \mathrm{~kg} / \mathrm{ha}$, the yield of fruit 73.707 and 73.737 gms per plant in average was significant over the other treatments on plant and their yields per plant, also over the chemical fertiliser treatment $50 \mathrm{~N}: 50 \mathrm{P}: 50 \mathrm{~K} \mathrm{~kg} / \mathrm{ha}$ (without biofertilisers) (Table 10).

Effect of NPK, some other macro and micro-nutrients with Pseudomonas striata and Azotobacter chroococcum on the yields of fruits per plants (\&ms) of Cajanus cajan Lin

After viewed for major nutrients from NPK-chemical fertilisers at different levels and biofertilisers, the selection at the $30 \mathrm{~N}: 30 \mathrm{P}: 30 \mathrm{~K} \mathrm{~kg} / \mathrm{ha}$ with combined inoculum of Pseudomonas striata and Azotobacter chroococcum treatments were kept constant and few macro and micro-nutrients were tested at 3-different levels of each element / nutrient.

Three levels of sulphur 20, 30 and $40 \mathrm{~kg} / \mathrm{ha}$ and combined inoculum of Pseudomonas striata species and Azotobacter chroococcum with $30 \mathrm{~N}: 30 \mathrm{P}: 30 \mathrm{~K}$ kg/ha applied to plants for yield per plants in grams. The results of these treatments showed yields 73.816, 75.227 and 74.308 gms yields per plant in average. Therefore, from table 11, it is evident that at $30 \mathrm{~kg} \mathrm{~S} / \mathrm{ha}$ and its yield per plant was found to be more significant over the 20 and 40 $\mathrm{kg} \mathrm{S} / \mathrm{ha}$ and over. No biofertiliser or treatment was with only chemical fertiliser at $50 \mathrm{~N}: 50 \mathrm{P}: 50 \mathrm{~K} \mathrm{~kg} / \mathrm{ha}$.

At same level of NPK - 30N:30P:30K kg/ha and $30 \mathrm{~kg}$ $\mathrm{S} / \mathrm{ha}$ with combined inoculum of two strains were tested at 40,50 and $60-\mathrm{Ca} \mathrm{kg} / \mathrm{ha}$. The results obtained from these wee $75.487,76.239$ and 75.851 gms yields per plants. At $50 \mathrm{~kg} \mathrm{Ca} / \mathrm{ha}$, the yield per plant was significant over other two treatments of 40 and $60 \mathrm{~kg} \mathrm{Ca} / \mathrm{ha}$ and also at only chemical fertiliser treatment $50 \mathrm{~N}: 50 \mathrm{P}: 50 \mathrm{~K} \mathrm{~kg} / \mathrm{ha}$ where yield was less.

Magnesium at different levels 10, 20 and $30 \mathrm{~kg} / \mathrm{ha}$ is experimented with the plants treated with combination of inoculum of two-strains with 30N:30P:30K:30S:50Ca $\mathrm{kg} / \mathrm{ha}$ (Table 11). The observations for yields per plant were $76.893,77.029$ and $76.983 \mathrm{gms}$. At $20 \mathrm{~kg}, \mathrm{Mg} / \mathrm{ha}$ was observed to be more significant over the 10 and $30 \mathrm{~kg}$ $\mathrm{Mg} / \mathrm{ha}$ and also over the only chemical treatment of $50 \mathrm{~N}: 50 \mathrm{P}: 50 \mathrm{~K} \mathrm{~kg} / \mathrm{ha}$ (Table 1).

The requirement of Zinc also experimented is at 5.0, 7.5 and $10.0 \mathrm{~kg} / \mathrm{ha}$ on plants which were treated with combined inoculum of Azotobacter chroococcum and Pseudomonas striata and 30N:30P:30K:30S:50Ca:20Mg $\mathrm{kg} / \mathrm{ha}$. The yields per plant were 79.123, 79.009 and $78.829 \mathrm{gms}$ thus it is assumed that the production per plant at $5.0 \mathrm{~kg} \mathrm{Zn} / \mathrm{ha}$ was more effective over the 7.5 and $10.0 \mathrm{~kg} \mathrm{Zn} / \mathrm{ha}$ and over the treatment with chemical 
fertilisers (without biofertiliser).

Iron concentration $5.0,10.0$ and $15.0 \mathrm{~kg} / \mathrm{ha}$ with the combination of Pseudomonas striata and Azotobacter chroococcum and fixed levels of chemical fertilisers30N:30P:30K:30S:50Ca:20Mg and $5.0 \mathrm{~kg} \mathrm{Zn} / \mathrm{ha}$ showed $15.0 \mathrm{~kg} \mathrm{Fe} / \mathrm{ha}$ was significant over the 5.0 and $10.0 \mathrm{~kg} \mathrm{Fe} / \mathrm{ha}$ and treatment with only chemical fertilizers NPK at $50 \mathrm{~N}: 50 \mathrm{P}: 50 \mathrm{~K} \mathrm{~kg} / \mathrm{ha}$.

The supplementation of Manganese at 10, 15 and 20 $\mathrm{kg} / \mathrm{ha}$ on plants treated with the 2-strains of biofertilisers and $30 \mathrm{~N}: 30 \mathrm{P}: 30 \mathrm{~K}: 30 \mathrm{~S}: 50 \mathrm{Ca}: 20 \mathrm{Mg}: 5 . \mathrm{OZn}$ and 15.0 $\mathrm{kg} / \mathrm{ha}$. (Table1). Iron $20.0 \mathrm{~kg} \mathrm{Fe} / \mathrm{ha}$ was found to be significant over the 15.0 and $10.0 \mathrm{~kg} \mathrm{Mn} / \mathrm{ha}$ levels and also over the chemical treatment (without biofertilisers). The results at 10,15 and $20 \mathrm{~kg} \mathrm{Mn} /$ ha were 82.631, 83.009 and $83.115 \mathrm{gms}$ yield/plant.

The copper also was needed by some plants, they were applied at $1.25,1.75$ and $2.5 \mathrm{~kg} / \mathrm{ha}$ to those plant which have treatment of 2-strains of biofertilisers with 30N:30P:30K:30S:50Ca:20Mg:5.OZn:15.OFe and 20Mn $\mathrm{kg} / \mathrm{ha}$. Their results were $83.893,83.935$ and $84.001 \mathrm{gms}$ yields per plant. The results, Table 11, it was clear that at $1.25 \mathrm{~kg} \mathrm{Cu} / \mathrm{ha}$ was significant over the remaining two copper levels 1.75 and $2.5 \mathrm{~kg} \mathrm{Cu} / \mathrm{ha}$ and also over the chemical fertilisers (without biofertilisers treatment).

Boron also supplemented at 3-doses of 1.0, 1.5 and 2.0 $\mathrm{kg} / \mathrm{ha}$ to the plants which have application of two-strains of biofertilisers and 30N:30P:30K:30s:50Ca: $20 \mathrm{Mg}: 5.0 \mathrm{Zn}: 15.0 \mathrm{Fe}: 20 \mathrm{Mn}: 1.25 \mathrm{Cu} \mathrm{kg} / \mathrm{ha}$ and the results obtained were $85.121,85.884$ and 85.925 gms yield per plant. The maximum gain of yield per plant from $2.0 \mathrm{~kg}$ $\mathrm{B} /$ ha was significant over the other levels of 1.0 and 1.5 $\mathrm{kg} \mathrm{B} / \mathrm{ha}$ and also oNer the chemical fertilisers.

Application of $0.5,1.0$ and $1.5 \mathrm{~kg} \mathrm{Mo} / \mathrm{ha}$ to the plant having treatment of 2 strains of biofertilisers Pseudomonas striata and Azotobacter chroococcum is with30N:30P:30K:30S:50Ca:20.Mg:5.0Zn:15.0Fe:20Mn: $1.25 \mathrm{Cu}: 2.0 \mathrm{~kg} / \mathrm{ha}$. In these treatment of boron, the yield resulted in $86.125,86.252,86.3521$ gms per plant. It is evident that at $1.5 \mathrm{~kg} \mathrm{Mo} / \mathrm{ha}$, the yield per plant was significant over the 0.5 and $1.0 \mathrm{~kg} \mathrm{Mo} / \mathrm{ha}$ and also over the chemical fertilisers treatments (without biofertilisers).

Some treatments were also carried out without application of biofertilisers but integration of all nutrients and obtained the results 61.139 gms per plant which was less than the results of treatment with chemical and bio-fertilisers.

Table 8. Effect of Pseudomonas striata, Azotobacter chroococcum and chemical fertiliser (NPK) on the plant height per plant(gms) of Cajanus cajan Lin

\begin{tabular}{|c|c|c|c|c|c|c|c|c|c|c|}
\hline Treatment & $\mathrm{T}$ & $\mathrm{T}_{1}$ & $\mathrm{~T}_{2}$ & $\mathrm{~T}_{3}$ & $\mathrm{~T}_{4}$ & $\mathrm{~T}_{5}$ & $\mathrm{~T}_{6}$ & $\mathrm{~T}_{7}$ & $\mathrm{~T}_{8}$ & $\mathrm{~T}_{9}$ \\
\hline Year 2018-19 & 81 & 100 & 105.50 & 107.50 & 126.00 & 136.00 & 138.00 & 148.00 & 120.00 & 146.00 \\
\hline Year 2019-20 & 80 & 100 & 108.50 & 107.00 & 127.00 & 132.00 & 134.00 & 148.00 & 120.00 & 145.00 \\
\hline
\end{tabular}

Table 9. Effect of Pseudomonas striata, Azotobacter chroococcum and chemical fertiliser (NPK) on the no. of fruits per plant (gms) of Cajanus cajan Lin

\begin{tabular}{|c|c|c|c|c|c|c|c|c|c|c|}
\hline Treatment & $\mathrm{T}$ & $\mathrm{T}_{1}$ & $\mathrm{~T}_{2}$ & $\mathrm{~T}_{3}$ & $\mathrm{~T}_{4}$ & $\mathrm{~T}_{5}$ & $\mathrm{~T}_{6}$ & $\mathrm{~T}_{7}$ & $\mathrm{~T}_{8}$ & $\mathrm{~T}_{9}$ \\
\hline Year 2018-19 & 11 & 14 & 17.00 & 19.00 & 18.00 & 32.00 & 37.00 & 33.00 & 32.00 & 30.00 \\
\hline Year 2019-20 & 11 & 13 & 15.00 & 19.00 & 19.00 & 36.00 & 36.00 & 34.00 & 28.00 & 36.00 \\
\hline
\end{tabular}

Table 10. Effect of Pseudomonas striata, Azotobacter chroococcum and chemical fertiliser (NPK) on the no. of fruits per plant (gms) of Cajanus cajan Lin

\begin{tabular}{|c|c|c|c|c|c|c|c|c|c|c|}
\hline Treatment & $\mathrm{T}$ & $\mathrm{T}_{1}$ & $\mathrm{~T}_{2}$ & $\mathrm{~T}_{3}$ & $\mathrm{~T}_{4}$ & $\mathrm{~T}_{5}$ & $\mathrm{~T}_{6}$ & $\mathrm{~T}_{7}$ & $\mathrm{~T}_{8}$ & $\mathrm{~T}_{9}$ \\
\hline Year 2018-19 & 30.52 & 33.21 & 34.62 & 36.13 & 50.24 & 72.28 & 73.71 & 72.30 & 72.27 & 49.64 \\
\hline Year 20019-20 & 32.05 & 33.34 & 34.41 & 37.02 & 50.35 & 72.39 & 72.74 & 72.61 & 72.26 & 48.91 \\
\hline
\end{tabular}


Table 11. Effects of NPK, some other Macro and Micro-nutrients with Pseudomonas striata and Azotobacter chroococcum on the yields of fruits per plants (gms) of Cajanus cajan Lin

\begin{tabular}{|c|c|c|c|c|}
\hline $\begin{array}{l}\text { Name of } \\
\text { Nutrients }\end{array}$ & $\begin{array}{l}\text { Application } \\
\text { of Nutrients } \\
\text { levels } \mathrm{Kg} / \mathrm{ha} \\
\end{array}$ & Treatments & $\begin{array}{l}\text { Fruits Yields in grams per plants at } \\
\text { 30N:30P:30K kg; ha with Pseudomonas } \\
\text { striata, Azotobacterchroococcum }\end{array}$ & $\begin{array}{c}\text { Fruit yields/ plant only in } \\
\text { chem. fert.50:50:50 NPK kg/ } \\
\text { ha }\end{array}$ \\
\hline \multirow{3}{*}{ S-Level } & 20 & $\mathrm{~T}_{10}$ & $73.816 \mathrm{gms}$ & \multirow{27}{*}{$13.65 \mathrm{gms}$} \\
\hline & 30 & $\mathrm{~T}_{\mathrm{I1}}$ & $75.227 \mathrm{gms}$ & \\
\hline & 40 & $\mathrm{~T}_{12}$ & $74.308 \mathrm{gms}$ & \\
\hline \multirow{3}{*}{ Ca-Level } & 0 & $\mathrm{~T}_{13}$ & $75.487 \mathrm{gms}$ & \\
\hline & 50 & $\mathrm{~T}_{14}$ & $76.239 \mathrm{gms}$ & \\
\hline & 60 & $\mathrm{~T}_{15}$ & $75.851 \mathrm{gms}$ & \\
\hline \multirow{3}{*}{ Mg-Level } & 10 & $\mathrm{~T}_{16}$ & $76.893 \mathrm{gms}$ & \\
\hline & 20 & $\mathrm{~T}_{17}$ & $77.029 \mathrm{gms}$ & \\
\hline & 30 & $\mathrm{~T}_{18}$ & $76.983 \mathrm{gms}$ & \\
\hline \multirow{3}{*}{ Zn-Level } & 5 & $\mathrm{~T}_{19}$ & $79.123 \mathrm{gms}$ & \\
\hline & 7.5 & $\mathrm{~T}_{20}$ & $79.009 \mathrm{gms}$ & \\
\hline & 10 & $\mathrm{~T}_{21}$ & $78.529 \mathrm{gms}$ & \\
\hline \multirow{3}{*}{ Fe-Level } & 5 & $\mathrm{~T}_{22}$ & $82.497 \mathrm{gms}$ & \\
\hline & 10 & $\mathrm{~T}_{23}$ & $82.689 \mathrm{gms}$ & \\
\hline & 15 & $\mathrm{~T}_{24}$ & $82.761 \mathrm{gms}$ & \\
\hline \multirow{3}{*}{ Mn-Level } & 10 & $\mathrm{~T}_{25}$ & $82.631 \mathrm{gms}$ & \\
\hline & 15 & $\mathrm{~T}_{26}$ & $83.009 \mathrm{gms}$ & \\
\hline & 20 & $\mathrm{~T}_{27}$ & $83.115 \mathrm{gms}$ & \\
\hline \multirow{3}{*}{$\mathrm{Cu}-\mathrm{Level}$} & 1.25 & $\mathrm{~T}_{28}$ & $83.893 \mathrm{gms}$ & \\
\hline & 1.75 & $\mathrm{~T}_{29}$ & $83.935 \mathrm{gms}$ & \\
\hline & 2.5 & $\mathrm{~T}_{30}$ & $84.001 \mathrm{gms}$ & \\
\hline \multirow{3}{*}{ B-Level } & 1 & $\mathrm{~T}_{31}$ & $85.121 \mathrm{gms}$ & \\
\hline & 1.5 & $\mathrm{~T}_{32}$ & $85.884 \mathrm{gms}$ & \\
\hline & 2 & $\mathrm{~T}_{33}$ & $85.925 \mathrm{gms}$ & \\
\hline \multirow{3}{*}{ Mo-Level } & 0.5 & $\mathrm{~T}_{34}$ & $86.125 \mathrm{gms}$ & \\
\hline & 1 & $\mathrm{~T}_{35}$ & $86.252 \mathrm{gms}$ & \\
\hline & 1.5 & $\mathrm{~T}_{36}$ & 86.354 gms - & \\
\hline
\end{tabular}

Only mixed treatment $\mathrm{T}_{37}=61.139$

\section{Summary and Conclusion}

The soils samples were collected from the different field sites of R. S. Bidkar College, Hinganghat. The soil samples were dried and analysed for salt contents. Rhizobium, Azotobacter, and Pseudomonas were cultured on auxenic agar plates as well as on liquid media of Norris and Date medium, Jensens's medium, and Pikovskaia's medium. The bacterial growth in culture media, modified media and mass culture were made in view to study their maximum growth and their influence on production of grain of few crop plants. Plots were prepared for sowing, seeds were sown, as normal practice and treated the seed with biofertilisers individually, in combination and with mineral fertilisers. Observations were made at different parameters, crops harvested, seeds collected, bagged, weighed analysed and stored.
The analysed soils showed the $\mathrm{pH} 7.0$ to 7.5 , the moisture contents ranges from the 0.09 to 0.13 and the electrical conductivity ranges from $0.02 \mathrm{dSm}^{-1}$ to 0.05 $\mathrm{dSm}-{ }^{1}$ from experimental fields to fields. The available Nitrogen in experimental fields of plants Cajanus cajan (Tur) was $332.41 \mathrm{~kg} / \mathrm{ha}$. The available $\mathrm{P}$ and $\mathrm{K}$ in fields were s 32.14, $228.9 \mathrm{~kg} / \mathrm{ha}$ in Cajanus cajan (Tur) Rhizobium sp., showed maximum growth in modified medium Norris and Date medium, $16 \mathrm{~g}$ mannitol, 1.6 Yeast extract, $0.75 \mathrm{~g} \mathrm{~K}_{2} \mathrm{HPO}_{4}, 0.91 \mathrm{~g} \mathrm{MgSO}_{4} .7 \mathrm{H}_{2} \mathrm{O}, 0.2 \mathrm{~g}$ $\mathrm{NaCl}$ and $0.0030 \mathrm{~g} \mathrm{FeCl}_{3} /$ Litre as compared to $10 \mathrm{~g}$ Mannitol, $1.0 \mathrm{~g}$ Yeast extract, $0.5 \mathrm{~g} \mathrm{~K}_{2} \mathrm{HPO}_{4}, 0.8 \mathrm{~g}$ $\mathrm{MgSO}_{4} .7 \mathrm{H}_{2} 0,0.2 \mathrm{~g} \mathrm{NaCI}$ and $0.01 \mathrm{~g} \mathrm{FeCl}_{3} \mathrm{~g} /$ Litre at 6.8 $\mathrm{pH}$.

The Azotobacter chroococcum was cultured in Jensen's liquid medium and observed maximum growth (optical density) in Jensen's modified medium containing $16.0 \mathrm{~g}$ 
sucrose, $1.27 \mathrm{~g} \mathrm{~K}_{2} \mathrm{HPO}_{4}, 0.625 \mathrm{~g} \mathrm{MgSO}_{4} .7 \mathrm{H}_{2} \mathrm{O}, 0.5 \mathrm{~g}$ $\mathrm{NaCl}$ and $0.6 \mathrm{~g} \mathrm{FeSO}_{4}, 1.97 \mathrm{~g} \mathrm{CaCO}_{3} \mathrm{~g} /$ Litre as compared to original contents of medium $20 \mathrm{~g}$ sucrose, $1.0 \mathrm{~g}$ $\mathrm{K}_{2} \mathrm{HPO}_{4}, 0.5 \mathrm{~g} \mathrm{MgSO}_{4} .7 \mathrm{H}_{2} \mathrm{O}, 0.5 \mathrm{~g} \mathrm{NaCl}$ and $0.1 \mathrm{~g} \mathrm{FeSO}_{4}$, $2.0 \mathrm{CaCO}_{3} \mathrm{~g} /$ Litre media at $\mathrm{pH} 7.0 \pm 0.1$.

Pseudomonas striata was cultured in Pikovskaia's liquid medium having $5.0 \mathrm{~g} \mathrm{Ca}_{3}\left(\mathrm{PO}_{4}\right)_{2}, 10.0 \mathrm{~g}$ sucrose, 0.5 $\mathrm{g}\left(\mathrm{NH}_{4}\right)_{2} \mathrm{SO}_{4}, 0.2 \mathrm{~g} \mathrm{NaCl}, 0.1 \mathrm{~g} \mathrm{MgSO}_{4} .7 \mathrm{H}_{2} \mathrm{O}, 0.2 \mathrm{~g} \mathrm{KCl}$, $0.5 \mathrm{~g}$ Yeast extract, $0.01 \mathrm{~g} \mathrm{MnSO}_{4}$ and $\mathrm{FeSO}_{4}$ (trace) per litre media. The maximum growth was obtained in modified Pikovskaia's medium having $4.76 \mathrm{~g} \mathrm{Ca}_{3}\left(\mathrm{PO}_{4}\right)_{2}$, $8.20 \mathrm{~g}$ sucrose, $0.42 \mathrm{~g}\left(\mathrm{NH}_{4}\right)_{2} \mathrm{SO}_{4}, 0.13 \mathrm{~g} \mathrm{NaCl}, 0.07 \mathrm{~g}$ $\mathrm{MgSO}_{4} .7 \mathrm{H}_{2} \mathrm{O}, 0.14 \mathrm{~g} \mathrm{KCl}, 0.46 \mathrm{~g}$ Yeast extract, $0.009 \mathrm{~g}$ $\mathrm{MnSO}_{4}$ and $0.01 \mathrm{~g} \mathrm{FeSO}_{4}$ per litre media at $\mathrm{pH} 7.0 \pm 0.2$.

In pulses, the maximum yield was obtained in treatments of triple inoculation with Rhizobium $s p$, Azotobacter and Pseudomonas and mineral fertilisers of 10: 20: 20:15:15:10: 2.5: 0.5: 5.0: 5.0: $0.5 \mathrm{~kg} /$ ha of N, P, $\mathrm{K}, \mathrm{S}, \mathrm{Ca}, \mathrm{Mg}, \mathrm{Zn}, \mathrm{Fe}, \mathrm{Mn}, \mathrm{Cu}, \mathrm{B}$ and Mo in Vigna crop over control, lower and higher of N. P, K, secondary and minor nutrients with biofertilisers. In Glycine, the maximum input observed in the treatment of triple inoculation of Rhizobium, Azotobacterand Pseudomonas with $20: 45: 45: 15: 30: 15: 10: 1.0: 5.0: 1.0: 1.0: 0.5 \mathrm{~kg} /$ ha $\mathrm{N}, \mathrm{P}, \mathrm{K}, \mathrm{S}, \mathrm{Ca}, \mathrm{Mg}, \mathrm{Zn}, \mathrm{Fe}, \mathrm{Mn}, \mathrm{Cu}, \mathrm{B}$ and $\mathrm{Mo}$ as compare to control, lower and higher of N. P, K, secondary and minor nutrients with biofertilisers.

In Cajanus cajan, the maximum yield was obtained in Rhizobium, Azotobacter and Pseudomonas with 15:30: 30: 30: 40: 30: 15: 1.5: 0.5: 0.5: 0.5: $0.5 \mathrm{~kg} /$ ha N, P, K, S, Ca, $\mathrm{Mg}, \mathrm{Zn}, \mathrm{Fe}, \mathrm{Mn}, \mathrm{Cu}, \mathrm{B}$ and $\mathrm{Mo}$ as compare to control.

The soil loss the nutrient contents due to exposure to excessive cropping. The local isolated strains of Rhizobium sp., Azotobacter, and Pseudomonas were always be beneficial to crop plants, they acclimatise easily with local flora of soil, works faster and solubilise mineral fastly. Further it was reported that the effect of individual, dual and triple inoculation of liquid biofertilisers with and without mineral nutrients, triple and dual inoculation with medium dose of mineral fertiliser was effective than lower and higher doses and resulted into higher yield or productivity.

First, while cropping, the nutrient level of the soil must be checked and analysed and according the mineral fertilisers should be applied. Secondly, the biofertilisers must be selected from local flora of soil for acclimatisation in that environment and proper moisture content must be maintain for flourishing the microflora of the soil. The use of Biofertilisers prevents the soil from degradation and elimination of other microorganism and they help in more production of grain, seeds, vegetable etc. and saving of cost of chemical fertilisers, fertility of soil, prevention of soil from degradation and elimination of other microorganisms.

\section{Acknowledgments}

I am very much thankful to Dr. Ushakiran Thute, President Gramin Vikas Sanstha for providing experimental field. I am also thankful to Dr. B. G. Ambatkar, Principal, R. S. Bidkar College and for providing laboratory facilities. I am also thankful to my guide Dr. L. P. Dalal, Associate Professor, Bajaj College of Science, Wardha I am also thankful to Dr. Sebastian Kulthassery, Associate Professor R. S. Bidkar College, Hinganghat for critiquing the manuscript.

\section{REFERENCES}

[1] Beijerinck, M.W. (1888)Die bacterien der papilionaceenknollchen. Bot. Ztg. 46. 72Er804.

[2] Beijerinck, M.W.(1925) Uber ein Spirillum. WelchesfreinStickstoffbindenKann? Zbl. Bakteriol. ParasitenkundeInfektionskr. Hyg. Abt. 2 (63): pp 353-359.

[3] Chhonkar,P.K. and Subba Rao, N.S.,(1967).Phosphate solubilization by fungi associated with legume root nodule.,Canadian J. microbial. 13, pp749-753.

[4] Cholodny, N.(1930)Uber eineneueMethodezuruntersuchung de Bodenmikroflora. Arclc. Mikrobiol., l: pp 620-652.

[5] Conn, H.J.(1918).The Microscopic Study of Bacteria and Fungi in Soil. N.Y. agric. Exp. Sta. Tech. Bull., 64.

[6] Harley, J.L and Waid, J.S.(1948).A method of studying active mycelia on living root and on other surfaces in the sol. Trans. Brit. Mycol. Soc. 38 : pp 104-118.

[7] Jensen, H.L., (1942)Nitrogen fixation in leguminous plants. I General characters of root nodule bacteria isolated from species of Medicrrgotrlfolltirllin Australia. Proc. Lirlrt. Soc., N.S.W., 66: pp 98-108.

[8] Norris, D.C., (1963).A porcelain bead method for storing Rhizobium. J. Exp. Agric., 31: pp 255-258

[9] Quispel, A. Ed. (1974)The Biology of Nitrogen Fixation. North Holland Publishing Co., Amsterdam.

[10] Singh, A.V., Rana, N.S. and Ahlawat., LP.S.,(1998).Effect of nitrogen, Rhizobium inoculation and phosphorus on growth and yield of Pigeon pea (Cajanuscajan) Ind. J. Agron. 43(2) :pp 358-361

[11] Subba Rao, LV. and Adinarayana, V., (1995)Role of PI. Nutrients in Crop Productivity. Micronictrient Research and Agricultural Production. Ed. Tandon, H.L.S. pp, 115-131, FDCO, New Delhi. 